\title{
RELATIONSHIP BETWEEN CLINICAL, PLACENTARY, OBSTETRIC AND NEONATAL ASPECTS AND INTRAUTERINE GROWTH IN HIGH RISK PREGNANCIES
}

\author{
Ana Karina Marques Salge ${ }^{1}$, Renata Calciolari Rossi e Silva², Janaína Valadares Guimarães ${ }^{3}$, Wilzianne Silva \\ Ramalho ${ }^{4}$ Douglas Reis Abdalla ${ }^{5}$ George Kemil Abdalla ${ }^{6}$
}

${ }^{1}$ Ph.D. in Health Sciences. Nursing Faculty and Post-graduate Program in Nursing Professor, Universidade Federal de Goiás (UFG). Goiânia, Goiás, Brazil. E-mail: anasalge@gmail.com

${ }^{2}$ Physiotherapist. Professor, Graduate Courses in Physiotherapy and Medicine, Universidade do Oeste Paulista. Presidente Prudente, São Paulo, Brazil. E-mail: renatacalciolari@terra.com.br

${ }^{3}$ Ph.D. in Health Sciences. Professor, Nursing Faculty and Post-graduate Program in Nursing, UFG. Goiânia, Goiás, Brazil. E-mail: guimaraesjv@hotmail.com

${ }^{4}$ M.Sc. in Nursing. Post-graduate Program in Nursing, UFG. Goiânia, Goiás, Brazil. E-mail: wilzianne.enf@gmail.com

${ }^{5}$ Ph.D. in Health and Medical Sciences. Professor, Faculdade de Telaentos Humanos (FACTHUS). Uberaba, Minas Gerais, Brazil, E-mail: drabdalla@facthus.edu.br

${ }^{6}$ Ph.D. in Health Sciences. Professor, FACTHUS. Uberaba, Minas Gerais, Brazil, E-mail: gkabdalla@facthus.edu.br

\begin{abstract}
Objective: to analyze clinical, placental and obstetric aspects of women with and without high-risk pregnancy, and their relationship with intrauterine growth deviations and neonatal aspects.

Method: this is a cross-sectional descriptive study. Data collection was based on an analysis of the medical records of women with and without high-risk pregnancy and newborns, and anatomopathological characterization of the placenta.

Results: 265 placentas were analyzed, 130 (49.06\%) women with high-risk pregnancy and newborns with intrauterine growth deviations. A higher occurrence of placental changes was found in high-risk pregnancy and uterine growth deviations in comparison to cases without high-risk pregnancy ( $\mathrm{p} \leq 0.001)$. High-risk pregnancies with intrauterine growth deviations were associated with placental changes ( $\mathrm{p} \leq 0.001)$. Intrauterine growth deviations was related to birth weight in cases of high-risk pregnancy compared to normal gestation ( $\mathrm{p}=0.014$ ).

Conclusion: a higher occurrence of placental anatomopathological changes was found in maternal and fetal surfaces in cases of high-risk pregnancy and intrauterine growth deviations.

DESCRIPTORS: Fetal growth retardation. High risk pregnancy. Neonatology. Placenta. Newborn.

\section{RELAÇÃO ENTRE OS ASPECTOS CLÍNICOS, PLACENTÁRIOS, OBSTÉTRICOS E NEONATAIS E O CRESCIMENTO INTRAUTERINO NA GESTAÇÃO DE ALTO RISCO}

\section{RESUMO}

Objetivo: analisar aspectos clínicos, placentários e obstétricos de mulheres com e sem gestação de alto risco e sua relação com desvios de crescimento intrauterino e aspectos neonatais.

Método: trata-se de um estudo descritivo transversal. A coleta de dados baseou-se em análise dos prontuários das mulheres com e sem gestação de alto risco e dos recém-nascidos, e análise anatomopatológica placentária.

Resultados: foram estudadas 265 placentas, 130 (49,06\%) de mulheres com gestação de alto risco e recém-nascidos com desvios de crescimento intrauterino. Houve maior ocorrência de alterações placentárias em gestação de alto risco e Desvios de crescimento uterino comparadas aos casos sem gestação de alto risco $(\mathrm{p} \leq 0,001)$. Gestação de alto risco com Desvios de crescimento intrauterino possui associação com alterações placentárias $(p \leq 0,001)$. desvios de crescimento intrauterino está relacionado ao peso ao nascer em casos com gestação de alto risco, comparados com gestação normal $(\mathrm{p}=0,014)$.

Conclusão: existe maior ocorrência de alterações anatomopatológicas placentárias nas faces materna e fetal nos casos com gestação de alto risco e desvios de crescimento intrauterino.

DESCRITORES: Retardo do crescimento fetal. Gravidez de alto risco. Neonatologia. Placenta. Recém-nascido. 


\title{
RELACIÓN ENTRE LOS ASPECTOS CLÍNICOS PLACENTARIOS, OBSTÉTRICOS Y NEONATALES Y EL CRECIMIENTO INTRAUTERINO EN LA GESTACIÓN DE ALTO RIESGO
}

\begin{abstract}
RESUMEN
Objetivo: analizar aspectos clínicos, placentarios y obstétricos de mujeres con y sin gestación de alto riesgo y su relación con desvíos de crecimiento intrauterino y aspectos neonatales.

Métodos: investigación descriptivo transversal. La recolección de datos se basó en el análisis de los expedientes de las mujeres con y sin gestación de alto riesgo y de los recién nacidos, y análisis anatomopatológico placentario.

Resultados: fueron estudiadas 265 placentas, 130 (49,06\%) de mujeres con gestación de alto riesgo y recién nacidos con desvíos de crecimiento intrauterino. Hubo mayor ocurrencia de alteraciones placentarias en gestación de alto riesgo y desvíos de crecimiento uterino comparados con los casos sin gestación de alto riesgo ( $\mathrm{p} \leq 0,001)$. Gestación de alto riesgo con desvíos de crecimiento intrauterino posee asociación con alteraciones placentarias $(\mathrm{p} \leq 0,001)$. Desvíos de crecimiento intrauterino están relacionados al peso al nacer en casos con gestación de alto riesgo, comparados con gestación normal $(\mathrm{p}=0,014)$.

Conclusión: existe mayor ocurrencia de alteraciones anatomopatológicas placentarias tanto en la madre como en el feto en los casos con gestación de alto riesgo y desvíos de crecimiento intrauterino.
\end{abstract}

DESCRIPTORES: Retardo del crecimiento fetal. Embarazo de alto riesgo. Neonatología. Placenta. Recién nacido.

\section{INTRODUCTION}

Most pregnancies progress without any complications, consisting of a necessary process of immune and systemic adaptation for the proper development of the fetus and the placenta. ${ }^{1}$ When the physiological and balanced gestational period undergoes alterations that can generate risk for the mother-child binomial, pregnancy is no longer considered a normal state, becoming high-risk pregnancy.

High-risk pregnancies are those in which the life or health of the mother and/or fetus/newborn are more likely to be threatened than the average population. A quantitative 10 to $20 \%$ of pregnant women have high-risk pregnancies, which is related to the occurrence of some disorders that represent risks to both the mothers and fetuses. ${ }^{2}$

Although the human placenta is a vital organ for maintaining pregnancy and promoting normal fetal development, ${ }^{3}$ a pattern of morphological alteration found may indicate maternal and fetal clinical involvement related to gestational hypertensive syndromes, ${ }^{4}$ to intrauterine growth restriction (IUGR), ${ }^{5}$ to Diabetes Mellitus (DM) or to placental abruption (PA), with small for gestational age (SGA) newborns, ${ }^{5}$ decreased placental flow (placental hypoxia) or miscarriage resulting as a consequence. ${ }^{6}$

Aggressions involving the uterine-placental unit may divert the fetus from its genetic growth potentia, ${ }^{7}$ resulting in a condition known as IUGR ${ }^{5}$ (Intrauterine Growth Restriction) and in complications related to a higher incidence of fetal distress, the presence of meconial amniotic fluid, low Apgar score, low birth weight (LBW) and perinatal death. ${ }^{3}$

Intrauterine growth deviations (IUGDs) are associated with perinatal morbidity and mortality, and the risk of developing diseases in adult life such as DM and cardiovascular diseases. IUGR and macrosomia represent important clinical conditions associated with this condition. ${ }^{8}$ Thus, the IUGR pathophysiology is related to changes in the availability, transport and use of the substrate occurring in three different situations: reduced maternal-placental supply; impaired fetal potential; or both being compromised. Placental and adnexa abnormalities are one of the main causes of IUGR. ${ }^{3}$ The incidence of mortality in preterm newborns is higher if IUGR is also present, increasing the perinatal mortality percentages by two to ten times. ${ }^{9}$

Just as IUGR may result in adults with diseases, macrosomia in adulthood can also trigger obesity, dyslipidemia, hypertension and type 2 diabetes. ${ }^{8}$ Fetal macrosomia is the term used to define fetuses or newborns considered abnormally large, weighing 4000 grams or more; large for gestational age (LGA) newborns are those who are above the $90^{\text {th }}$ percentile for gestational age. ${ }^{10}$

DM is a known risk factor for excessive newborn weight. Macrosomia is observed among cases with poorly controlled diabetes, those with long evolution and those with vascular alterations. ${ }^{8}$

Understanding the relevance of IUGDs as a predisposing factor to the increased risk of fetal/ neonatal morbidity and mortality, and recognizing deviations as well as their etiopathogenesis is extremely important, ${ }^{9}$ being a fundamental task in quality prenatal care. ${ }^{11}$

In addition, proper knowledge of altered birth weight associated with maternal data, as well as the etiopathogenesis of the disease that led to this outcome are important in evaluating IUGDs, since these conditions represent a serious public health 
problem due to the intercurrences that affect mothers and newborns at prenatal, delivery and in the puerperium periods, and they can be predictors of fetal changes in future pregnancies.

Thus, the objective of the present study was to relate obstetrical, fetal and anatomopathological aspects of maternal and fetal surfaces of the placentas of women with and without high-risk pregnancy, and their relationship with intrauterine growth deviations in a public maternity hospital in Goiânia-GO, Brazil.

\section{METHOD}

This is a descriptive cross-sectional study carried out from January 2010 to January 2015, in a public maternity hospital in Goiânia-GO, Brazil. The population consisted of 265 women presenting 130 with high-risk pregnancies and 135 without highrisk pregnancies, who had their medical records available for data collection with complete information, including newborn weight at birth, gestational age and placenta available for evaluation.

Data collection took place in two distinct stages: review of medical records and placental macroscopic anatomopathological analysis, according to the protocols by Driscoll and Langston. ${ }^{5}$ The eligibility criteria considered in the high-risk pregnancy and IUGD group were women with high-risk pregnancies who presented risk factors for fetuses/newborns with IUGD. All participants signed the Clear and Informed Consent Form (TCLE).

The group without high-risk pregnancy and without IUGDs included women without high-risk pregnancy, mothers of fetuses/newborns who did not present any disease considered risk factors for fetuses/newborn with IUGD during the gestation, those who did not present intercurrences during gestation and delivery evidenced by laboratory results, as well as clinically normal fetuses/newborns who did not present IUGD according to the criteria established in $1963 .^{3}$

All cases that did not meet the eligibility criteria were considered as exclusion criteria; all cases in which the placenta was not available for analysis (not stored at a temperature of approximately $25^{\circ} \mathrm{C}$ in $0.9 \%$ saline solution, but in formaldehyde and was sent to the hospital's pathology service) (four cases); all cases in which the medical record was not available (five cases), was incomplete or missing information (11 cases) such as birth weight and/or gestational age; and also participant's or the person in charge refusing to sign the TCLE, or refusing to participate in the study (two cases).

For the macroscopic analysis, placentas stored in $0.9 \%$ saline solution for up to 48 hours postpartum were analyzed. All macroscopic changes found on maternal and/or fetal surfaces of the placenta and on the umbilical cord were evaluated, recorded and photographed.

The information source for this study was composed of the medical records of each patient, from where sociodemographic data (age, nationality, education level, occupation, family income); baseline diseases, gestational age (determined by the date of the last menstrual period, at the first trimester ultrasound examination, and by the Capurro Method) and parity were collected and transcribed onto a separate form. Maternal-baseline diseases were grouped according to the criteria established by the $10^{\text {th }}$ Revision of the International Classification of Diseases (ICD-10).

The ethical principles of research involving human beings were respected, in accordance with Resolution 196/96.12 The research project was submitted and approved by the Human and Animal Medical Research of the Hospital das Clinicas of the Universidade Federal de Goiás, under protocol number 101/2008. A CAAE number was not generated since the project was approved prior to the creation of the Plataforma Brasil in 2012.

The information was analyzed through the

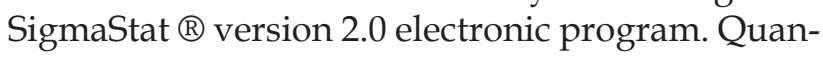
titative data were descriptively analyzed through frequency distribution, means and standard deviation. Significance tests appropriate to the sample size were applied to verify statistical differences between proportions. Proportions were compared using the $\chi^{2}$ test, followed by the Yates' correction test. The differences found between the groups were verified using the Mann-Whitney test. Differences where $p$ was less than $5 \%(p<0.05)$ were considered statistically significant.

\section{RESULTS}

A total of 265 placentas were studied, with 130 $(49.06 \%)$ being women with high-risk pregnancy and fetuses/newborns with IUGDs. The remaining $135(50.94 \%)$ placentas corresponded to the group of women without high-risk pregnancy and fetuses/ newborns without IUGDs. No twin pregnancies were included during the study; therefore, the number of pregnant women coincides with the number of fetuses/newborns. 
Regarding maternal age, 107 (82.3\%) women were between 19 and 35 years of age, eight women $(6.15 \%)$ were under 18 years of age, and 15 women (11.55\%) were in the age group above 35 years. Mean maternal age was $28.12 \pm 6.2$ years in the high-risk pregnancy group.

The comparison between the occurrence of macroscmpic anatomopathological changes on maternal and fetal surfaces of the placenta in cases of high-risk pregnancy and newborns with IUGD, and cases of women without high-risk pregnancy and newborns without IUGD (control group) was statistically significant $(\mathrm{p}<0.05$, maternal surface, and $\mathrm{p}<0.05$, fetal surface). The occurrence of macroscopic placental abnormalities was more prevalent in maternal and fetal surfaces in cases with highrisk pregnancy and IUGD (Table 1).

Table 1 - Comparison between the occurrence of macroscopic anatomopathological changes on the maternal and fetal surfaces of the placenta in women with and without high-risk pregnancy and their respective newborns with intrauterine growth deviation in a public maternity hospital in Goiânia-GO, Brazil, from January 2010 to January 2015

\begin{tabular}{|c|c|c|c|c|}
\hline \multirow[t]{2}{*}{ Placental anatomopathological changes } & \multicolumn{3}{|c|}{$\begin{array}{c}\text { High-risk pregnancy and intrauterine growth } \\
\text { deviations }\end{array}$} & \multirow[t]{2}{*}{$\mathrm{p}^{*}$} \\
\hline & Yes & No & Total & \\
\hline \multicolumn{5}{|l|}{ Maternal surface } \\
\hline Yes & 27 & 62 & 89 & \multirow{2}{*}{$\mathrm{p}<0.05$} \\
\hline No & 4 & 31 & 35 & \\
\hline Total & 31 & 93 & 124 & \\
\hline \multicolumn{5}{|l|}{ Fetal surface } \\
\hline Yes & 27 & 59 & 86 & \multirow{2}{*}{$\mathrm{p}<0.05$} \\
\hline No & 2 & 28 & 30 & \\
\hline Total & 29 & 87 & 116 & \\
\hline
\end{tabular}

${ }^{*} \chi^{2}$ test, followed by the Yates' correction test.

Macroscopic anatomopathological changes in the maternal and fetal surfaces of the placentas of women with high-risk pregnancy are described in Table 2. Calciphylaxis and fibrin were the most prevalent changes in maternal and fetal surfaces $(\mathrm{p}<0.0001)$; calciphylaxis was more frequent on the maternal surface $(\mathrm{p}<0.0001)$ and fibrin on the fetal surface $(\mathrm{p}<0.0001)$.

Table 2 - Frequency of macroscopic anatomopathological changes in the maternal and fetal surfaces of the placentas of 130 women with high-risk pregnancy associated with intrauterine growth deviations in a public maternity hospital in Goiânia-GO, Brazil, from January 2010 to January 2015

\begin{tabular}{|c|c|c|c|}
\hline Macroscopic anatomopathological changes & $\begin{array}{c}\text { Maternal surface } \\
\text { n ( } \%)\end{array}$ & $\begin{array}{c}\text { Fetal surface } \\
\text { n }(\%)\end{array}$ & $\begin{array}{l}\text { Maternal surfasse vs } \\
\text { Fetal surface }\end{array}$ \\
\hline Calciphylaxis & $75(57.7)^{*}$ & $18(13.84) \dagger$ & $\mathrm{p}<0.0001$ \\
\hline Fibrin & $31(23.84)^{*}$ & $102(78.5) \dagger$ & $\mathrm{p}<0.0001$ \\
\hline Infarction & $1(0.76)$ & $1(0.76)$ & \\
\hline Detachment Area/abruption site & $1(0.76)$ & - & \\
\hline Fibrosis & $3(2.3)$ & - & \\
\hline Bruising & - & $3(2.3)$ & \\
\hline Total changes & $111(85.4)$ & $124(95.4)$ & \\
\hline No changes & $19(14.6)$ & $6(4.6)$ & \\
\hline
\end{tabular}

Neonatal factors related to intrauterine growth deviations in women with high-risk pregnancy are described in Table 3. Newborns with IUGD had a higher prevalence $(\mathrm{p}<0.05)$ of factors related to IUGD. 
Table 3 - Neonatal factors related to intrauterine growth deviation in newborns of women with highrisk pregnancy in a public maternity hospital in Goiânia-GO, Brazil, from January 2010 to January 2015

\begin{tabular}{lcccc}
\hline $\begin{array}{l}\text { Neonatal factors related to } \\
\text { intrauterine growth deviation }\end{array}$ & $\begin{array}{c}\text { Normal pregnancy } \\
\mathbf{n}(\%)^{*}\end{array}$ & $\begin{array}{c}\text { High-risk pregnancy } \\
\mathbf{n}(\%)^{*}\end{array}$ & Odds Ratio (95\% $\mathbf{C I})^{\dagger}$ & $\mathbf{p}$ \\
\hline $\begin{array}{l}\text { Cephalic perimeter } \\
(<32 \text { and }>38 \text { centimeters) }\end{array}$ & $10(8.0)$ & $25(23.8)$ & $0.34(0.15-0.73)$ & $\mathbf{0 . 0 0 6}$ \\
$\begin{array}{l}\text { Thoracic perimeter } \\
\text { (<30 and }>36 \text { centimeters) }\end{array}$ & $19(16.4)$ & $34(35.4)$ & $0.46(0.25-0.86)$ & $\mathbf{0 . 0 1 7}$ \\
$\begin{array}{l}\text { Abdominal perimeter }(<28 \text { and } \\
>34 \text { centimeters) }\end{array}$ & $11(8.8)$ & $24(22.6)$ & $0.39(0.18-0.84)$ & $\mathbf{0 . 0 2 1}$ \\
$\begin{array}{l}\text { NB weight } \\
\text { (<2.500 and }>4.000 \text { grams) }\end{array}$ & $11(8.8)$ & $29(28.7)$ & $0.31(0.15-0.65)$ & $\mathbf{0 . 0 0 2}$ \\
Apgar at $1(<8$ points) & $30(28.6)$ & $45(52.9)$ & $0.54(0.31-0.93)$ & $\mathbf{0 . 0 3 0}$ \\
Apgar at 5 (<8 points) & $3(2.2)$ & $4(3.2)$ & $0.72(0.16-3.2)$ & 0.718 \\
\hline
\end{tabular}

${ }^{*}$ n: number of cases; $\uparrow 95 \%$ CI: 95\% of the confidence interval. The proportions were compared by the $\chi^{2}$ test, followed by the Yates' correction test.

According to the newborn classification and considering the relation between birth weight and gestational age (BW versus GA) according to the neonatal measurement curve $^{3}$ related to the IUGD,
$20(15.38 \%)$ NBs were classified as SGA, 7 (5.38\%) as LGA and $94(72.31 \%)$ as appropriate for gestational age (AGA) (Table 4).

Table 4 - Classification of newborns with intrauterine growth deviation using the birth weight and gestational age ratio, according to a graph adapted from Lubchenco (1963), from high-risk pregnancy in a public maternity hospital in Goiânia-GO, Brazil, from January 2010 to January 2015

\begin{tabular}{lc}
\hline NB Classification & $\mathbf{n}(\%)$ \\
\hline Small for gestational age & $20(15.39)$ \\
Large for gestational age & $7(5.38)$ \\
Appropriate for gestational age & $94(72.31)$ \\
Birth weight not available & $9(6.92)$ \\
\hline Total & $\mathbf{1 3 0 ( 1 0 0 )}$ \\
\hline
\end{tabular}

Data on the association between newborn classification based on the criteria (BW versus GA) ${ }^{3}$ in high-risk pregnancy and normal gestation in 130 women with and without macroscopic placental changes, respectively, are described in Table 5.

Table 5 - Birth weight versus gestational related to intrauterine growth deviation, and associated to high-risk pregnancy and anatomicopathological macroscopic placental changes in a public maternity hospital in Goiânia-GO, Brazil, from January 2010 to January 2015

\begin{tabular}{lccc}
\hline Gestational age vs birth weight & $\begin{array}{c}\text { High-risk pregnancy } \\
\text { (with placental change) }\end{array}$ & $\begin{array}{c}\text { Normal pregnancy } \\
\text { (without placental change) }\end{array}$ & p \\
\hline Small for gestational age & 26 & 54 & $<0.05$ \\
Appropriate for gestational age & 58 & - & 0.4583 \\
Large for gestational age & 20 & $<0.05$ \\
\hline
\end{tabular}

${ }^{*} \chi^{2}$ test, followed by the Yates' correction test.

A statistically significant difference $(p \leq 0.001)$ was observed when comparing the occurrence of SGA and LGA (Intrauterine growth deviations) with the occurrence of high-risk pregnancy (with placental changes) and normal pregnancy (no placental changes); and a higher number of SGA and 
LGA (NB births with IUGD) in cases of high-risk pregnancy (with macroscopic placental changes) was observed than in cases of normal pregnancy (without macroscopic placental changes). Cases of gestational diabetes $(33.07 \%)$ and preeclampsia $(26.15 \%)$ can be highlighted among maternal predictors of high-risk pregnancy associated with IUGD (Table 6).

Table 6 - Maternal factors related to intrauterine growth deviation in women with high-risk pregnancy at a public maternity hospital in Goiânia-GO, Brazil, from January 2010 to January 2015

\begin{tabular}{lc}
\hline Maternal factors related to intrauterine growth deviation & $\mathbf{n}(\mathbf{\%})$ \\
\hline Maternal age & $26(20.00)$ \\
$\quad \leq 18$ years and $\geq 36$ years & $29(22.30)$ \\
Gestational age & \\
$\quad<37$ weeks and $>41$ weeks and 6 days & $34(26.15)$ \\
Maternal Diseases & $3(2.31)$ \\
$\quad$ Preeclampsia & $18(13.85)$ \\
Eclampsia & $11(08.46)$ \\
Chronic hypertension & $1(0.77)$ \\
Gestational hypertension & $43(33.07)$ \\
HELLP syndrome & $15(11.54)$ \\
Gestational diabetes & $5(3.85)$ \\
Diabetes Mellitus I & \\
Diabetes Mellitus II & \\
\hline
\end{tabular}

\section{DISCUSSION}

This study evaluated 265 placentas, with 130 $(49.06 \%)$ from women with high-risk pregnancy and fetuses/newborns with IUGD. The presence of macroscopic anatomopathological changes in the maternal and fetal surfaces of the placenta is associated with the occurrence of high-risk pregnancy IUGD in the investigated group.

Mean maternal age in the high-risk pregnancy group was $28.12 \pm 6.2$ years. A similar finding was found in a study that investigated the sociodemographic characteristics of women with high-risk pregnancy with newborns with IUGD. The mean maternal age was $30.1 \pm 1.4$ years. ${ }^{13}$

A case-control study conducted in Chile with 22,227 newborns showed that there is a significant relationship between the occurrence of IUGR and maternal age. ${ }^{14}$ In another study conducted in India based on 36,674 births, a statistical association was found among births of SGA newborns with maternal age above 35 years. In addition, we found that maternal age below 19 years is a determinant of low birth weight (LBW). ${ }^{15}$ Maternal age extremes can be considered a risk factor and influence perinatal mortality.

By comparing the occurrence of macroscopic anatomopathological changes found on the maternal and fetal surfaces of the placenta in women with high-risk pregnancy and newborns with IUGD with the control group, it was possible to verify a higher occurrence in the former, as well as presenting statistical significance $(\mathrm{p} \leq 0.001)$.

Several placental changes were observed in a study carried out in Japan observing 53,650 placentae of pregnant women with high-risk pregnancy, mainly related to placental weight. ${ }^{16}$

A higher prevalence of calciphylaxis and fibrin on both maternal and fetal surfaces was found in analyzing maternal and fetal surfaces of pregnant women with high-risk pregnancies regarding the presence and type/characteristic of macroscopic anatomopathological changes; however, a higher prevalence of calciphylaxis $(57.7 \%)$ was found on the maternal surface $(\mathrm{p}<0.0001)$, and fibrin on the fetal surface $(78.5 \%)(\mathrm{p}<0.0001)$.

Divergent results were found in another sample with 518 placentas. The most frequent lesion was chorionic degenerative vascular injury (55.7\%), followed by retroplacental hematoma $(23.8 \%)$, infarction areas $(10.9 \%)$ and fibrin deposits $(9.2 \%) .{ }^{17}$

Fibrin deposits in the placenta reflect important vascular changes, which can cause spontaneous abortion, preterm birth, IUGD and fetal death. In a study carried out in Romania of 467 placentas examined macroscopically, around 188 (40\%) had a fibrin deposit. Alterations such as thrombosis and intervillous stasis, retroplacental hemorrhage and 
recent infarcts were found on the fetal surface. On the maternal surface, important areas of placental infarction have been reported, which may contribute to the occurrence of IUGD by restricting the surface exchange area. ${ }^{18}$

Cases with no changes were found in both the maternal surface as well as the fetal surface analyzes, corresponding to a previously described study ${ }^{18}$ where placental morphological changes that were absent in $279(60 \%)$ placentas were analyzed from a total of 467 placentas examined macroscopically.

A comparison between the cases of women with high-risk pregnancy and newborns with IUGD was carried out, with the cases of women without high-risk pregnancy showing statistical significance $(p \leq 0.001)$. Cases with high-risk pregnancy and IUGD have a higher statistical association with the occurrence of macroscopic anatomopathological changes.

Some high-risk pregnancies have been associated with both specific macroscopic and microscopic placental changes. In placentas from SGA newborns (an important type of IUGD) an increase in ischemic lesions, infarctions and calcium and fibrin deposition has been observed. ${ }^{19}$

In analyzing the data of fetuses/newborns regarding perimeters (cephalic- $\mathrm{CP}$, thoracic - TP, and abdominal - AP, measured in centimeters), 25 (23.8\%) among the 130 fetuses/newborns included in the study with case group criteria presented $\mathrm{CP}$ with IUGD at the time of investigation and data collection. Regarding TP, 34 (35.4\%) cases with IUGD were included, and 24 (22.6\%) cases for AP with IUGD were included. Regarding birth weight, 29 (28.7\%) fetuses/newborns presenting IUGD birth weight were included. As for Apgar data at 1 minute, $45(52.9 \%)$ cases with Apgar $<8$ points and 4 $(3.2 \%)$ cases with Apgar $<8$ points in the $5^{\text {th }}$ minute were included.

There are many ways to diagnose perinatal hypoxia, and one of them is the Apgar score. Several placental changes such as infarction reflect fetal distress diagnosed by Apgar indices below 7 at the $5^{\text {th }}$ minute, ${ }^{20}$ suggesting the importance of studying the relationship between fetal distress (evaluated through Apgar) and placental changes.

Mean cephalic circumference found in this study was $33.00 \pm 4.83 \mathrm{~cm}$. This differs from a retrospective cohort study performed in Zona da Mata of Pernambuco, Brazil, with 915 full-term children, in which the mean cephalic circumference was $34.5 \pm 1.16$ for NBs without IUGD, 33.1 \pm 1.24 for LBW NBs, and $35.4 \pm 1.13$ for macrosomic NBs. ${ }^{21}$
Cephalic perimeter can translate into pathological brain growth (hydrocephalus, microcephaly). Growth restriction of fetal segments in intrauterine life may be associated with the presence of maternal affections, such as hypertension due to placental hypoxia, placentation alteration, as well as oxygen and nutrient supply. This condition may alter bone formation and fetal organs, thus interfering with neonatal anthropometric measures such as head circumference and weight. ${ }^{22}$

When comparing the occurrence of SGA and LGA (IUGD) births with the occurrence of high-risk pregnancy (with placental changes) and normal pregnancy (no placental changes), a statistically significant difference ( $\mathrm{p} \leq 0.001)$ was found, evidencing a greater number of SGA and LGA (NB births with IUGD) in cases of high - risk pregnancy (with macroscopic placental changes) than in cases of normal pregnancy (without macroscopic placental changes).

As for the comparison between the occurrence of high-risk pregnancy and macroscopic anatomopathological changes with neonatal clinical data (AI and BW) and maternal data (maternal age and GA), a statistically significant difference was found only when comparing the occurrence of macroscopic anatomopathological changes and neonatal clinical data related to BW $(\leq 2,500 \mathrm{~g}$ and $>4,000 \mathrm{~g})$. Regarding post-term pregnancy, no statistically significant difference was found between groups.

Considering the maternal predictor "gestational age", the lower the maternal age, the greater the risk of preterm birth and the interruption of breastfeeding, ${ }^{23}$ especially before the age of 15 years. Pregnant women of extreme ages (below 19 years and above 35 years) were also at higher risk for maternal and neonatal mortalities. ${ }^{24}$

The study presented some limitations in being a transversal descriptive study carried out with medical records and macroscopic placental analysis. Some information was often incomplete or inadequately recorded, with no standardization for the record. Thus, a great amount of information was lost, such as information about maternal disease history or newborn's anthropometric data due to illegible handwriting and lack of records by the nursing team.

\section{CONCLUSION}

The results of this study have shown that there is a relationship between IUGDs and obstetric, fetal and placental aspects of women with and without 
high-risk pregnancy. There was a greater occurrence of macroscopic anatomopathological changes in maternal and fetal surfaces of the placenta in cases of high-risk pregnancy and IUGD $(p=0.029$, maternal surface and $p=0.007$, fetal surface). Among the macroscopic anatomopathological changes, calciphylaxis and fibrin were the most prevalent changes in maternal and fetal surfaces $(p<0.0001)$, with calciphylaxis being more frequent in the maternal surface $(\mathrm{p}<0.0001)$ and fibrin in the fetal surface $(\mathrm{p}<0.0001)$.

Neonatal factors such as weight were statistically significant in NB with IUGD ( $p<0.05)$. A higher number of SGA and LGA (NB with IUGD) was observed in cases of high-risk pregnancy (with macroscopic placental changes) than in cases of normal pregnancy (without macroscopic placental changes). Gestational diabetes (33.07\%) and pre-eclampsia (26.15\%) were among the maternal predictors of high-risk pregnancy associated with IUGD.

Studying IUGDs related to obstetric, fetal and placental aspects of women with and without highrisk pregnancy deserves a vigilant and multiprofessional approach. Understanding the factors related to IUGD can positively contribute to health team conduct, who should provide specific and quality care when carrying for newborns with IUGD in order to design care strategies that contemplate the newborn's/child's growth and development needs. Guidance can also be offered during women's health and prenatal consultations, with the intention to inform about possible intercurrences that may be predictive of fetal changes in future pregnancies.

\section{REFERENCES}

1 Orczyk-Pawilowicz M, Jawien E, Deja S, Hirnle L, Zabek A, Mlynarz P. Metabolomics of human amniotic fluid and maternal plasma during normal pregnancy. PLoS One [Internet]. 2016 Apr 12 [cited 2016 Apr 25];11(4):e0152740. Available from: http:/ / www.ncbi.nlm.nih.gov/pmc/articles/PMC4829258/ pdf/pone.0152740.pdf

2 Ministério da Saúde (BR). Secretaria de Atenção à Saúde. Departamento de Atenção Básica. Gestação de alto risco: manual técnico. Brasília (DF): MS; 2012.

3 Lubchenco LO, Hansman C, Dressler M, Boyd E. Intrauterine growth as estimated from liveborn birthweight data at 24 to 42 weeks of gestation. Pediatrics. 1963; 32:793-800.

4 Żyła MM, Wilczyński J, Nowakowska-Głąb A, Maniecka-Bryła I, Nowakowska D. pregnancy and delivery in women with uterine malformations. Adv Clin Exp Med [Internet]. 2015 Sep-Oct [cited 2016 Apr 25];24(5):873-9. Available from: http://www. advances.am.wroc.pl/pdf/2015/24/5/873.pdf
5 Driscoll SG, Langston C. Placental examination in a clinical setting. Arc Pathol Lab Med. 1991;115(7):668-71.

6 Daniel-Spiegel E, Mandel M, Nevo D, Ben-Chetrit A, Shen O, Shalev E, et al. Fetal biometry in the Israeli population: new reference charts. Isr Med Assoc J [Internet]. 2016 Jan [cited 2016 Apr 25];18(1):40-4. Available from: http:/ / www.ima.org. il/FilesUpload/IMAJ/0/183/91559.pdf

7 Amaral LM, Cunningham MW Jr, Cornelius DC, LaMarca B. Preeclampsia: long-term consequences for vascular health. Vasc Health Risk Manag [Internet]. 2015 Jul [cited 2016 Apr 25];11:403-15. Available from: http:/ / www.ncbi.nlm.nih.gov/pmc/articles/ PMC4508084/pdf/vhrm-11-403.pdf

8 Juárez-Olguín H, Buendía-Soto E, Lares-Asseff I. Pharmacology for the fetus and the newborn]. Gac Med Mex [Internet]. 2015 May-Jun [cited 2016 Apr 25];151(3):387-95. Available from: http://www.anmm. org.mx/GMM/2015/n3/GMM_151_2015_3_387-395.pdf

9 Kamana Kc, Shakya S, Zhang H. Gestational diabetes mellitus and macrosomia: a literature review. Ann Nutr Metab [Internet]. 2015[cited 2016 Apr 25];66 Suppl 2:14-20. Available from: http://www.karger. com/Article/Pdf/371628

10 Kintiraki E, Papakatsika S, Kotronis G, Goulis DG, Kotsis V. Pregnancy-induced hypertension. Hormones (Athens) [Internet]. 2015 Apr-Jun [cited 2016 Apr 25];14(2):2112-23. Available from: http:/ / www.hormones.gr/8566/article/article.html

11 Zhang S, Regnault TR, Barker PL, Botting KJ, McMillen IC, McMillan CM, et al. Placental adaptations in growth restriction. Nutrients [Internet]. 2015 Jan [cited 2016 Apr 25];7(1):360-89. Available from: http:/ / www.ncbi.nlm.nih.gov/pmc/articles/PMC4303845/ pdf/nutrients-07-00360.pdf

12 Ministério da Saúde (BR). Conselho Nacional de Saúde. Resolução 196 de 10 de outubro de 1996. Aprova as diretrizes e normas regulamentadoras da pesquisa envolvendo seres humanos. Brasília (DF): MS; 1996. Available from: http:/ / conselho.saude.gov. br/Resolucoes/Reso196.doc

13 Albu AR, Horhoianu IA, Dumitrascu MC, Horhoianu V. Growth assessment in diagnosis of fetal growth Restriction. Review. J Med Life [Internet]. 2014 Jun [cited 2016 Apr 25];7(2):150-4. Available from: http:/ / www.ncbi.nlm.nih.gov/pmc/articles/PMC4197512/ pdf/JMedLife-07-165.pdf

14 Canals C A, Cavada C G, Nazer H J. Identification of risk factors for congenital malformations. Rev Med Chil [Internet]. 2014 Nov [cited 2016 Apr 25];142(11):1431-9. Available from: http://www. scielo.cl/pdf/rmc/v142n11/art10.pdf

15 Sebastian T, Yadav B, Jeyaseelan L, Vijayaselvi R, Jose R. Small for gestational age births among South Indian women: temporal trend and risk factors from 1996 to 2010. BMC Pregnancy Childbirth [Internet]. 2015 Feb 3 [cited 2016 Apr 25];15:7-17. Available from: http:/ / 
www.ncbi.nlm.nih.gov/pmc/articles/PMC4324804/ pdf/12884_2015_Article_440.pdf

16 Matsuda Y, Ogawa M, Nakai A, Hayashi M, Satoh S, Matsubara S. Fetal/Placental weight ratio in term Japanese pregnancy: its difference among gender, parity, and infant growth. Int J Med Sci [Internet]. 2015 Mar 25 [cited 2016 Apr 25];12(4):301-5. Available from: http://www.ncbi.nlm.nih.gov/pmc/articles/ PMC4402432/pdf/ijmsv12p0301.pdf

17 Folescu R, Motoc AG, Zamfir CL, Ilie AC. Anatomical and histological considerations of placenta vascular diseases with implications in forensic medicine. Rom J Morphol Embryol [Internet]. 2014 [cited 2016 Apr 25];55(2 Suppl):579-83. Available from: http:// www. rjme.ro/RJME/resources/files/551214579583.pdf

18 Pinar H, Goldenberg RL, Koch MA, Heim-Hall J, Hawkins HK, Shehata B, et al. Placental findings in singleton stillbirths. Obstet Gynecol [Internet]. 2014 Feb [cited 2016 Apr 25];123(2Pt1):325-36. Available from: http://www.ncbi.nlm.nih.gov/pmc/articles/ PMC3948332/pdf/nihms541867.pdf

19 Wise LA, Mikkelsen EM, Sørensen HT, Rothman KJ, Hahn KA, Riis AH, et al. Prospective study of time to pregnancy and adverse birth outcomes. Fertil Steril [Internet]. 2015 Apr [cited 2016 Apr 25];103(4):1065-73. Available from: http://www.ncbi.nlm.nih.gov/pmc/ articles/PMC4394049/pdf/nihms666521.pdf

20 Fadigas C, Saiid Y, Gonzalez R, Poon LC, Nicolaides $\mathrm{KH}$. Prediction of small-for-gestational-age neonates: screening by fetal biometry at 35-37 weeks. Ultrasound
Obstet Gynecol [Internet]. 2015 May [cited 2016 Apr 25];45(5):559-65. Available from: http:/ / onlinelibrary. wiley.com/doi/10.1002/uog.14816/epdf

21 Gonçalves FC, Lira PI, Eickmann SH, Lima M de C. Weight/head circumference ratio at birth for assessing fetal growth.CadSaudePublica[Internet].2015Sep [cited 2016 Apr 25];31(9):1995-2004. Available from: http:/ / www.scielo.br/scielo.php?script=sci_arttext\&pid= S0102311X2015000901995\&lng $=$ en\&nrm $=$ iso\&tlng $=$ en

22 Amare EB, Idsøe M, Wiksnes M, Moss T, Roelants $M$, Shimelis D, et al. Reference ranges for head circumference in Ethiopian vhildren $0-2$ years of age. World Neurosurg [Internet]. 2015 Dec [cited 2016 Apr 25];84(6):1566-71. Available from: http://www.worldneurosurgery.org/article/S18788750(15)01061-X/pdf

23 Abreu FCP, Marski BSL, Custódio NC, Carvalho SC, Wernet M. Breastfeeding preterm infants at home. Texto Contexto Enferm [Internet]. 2015 Out-Dez [cited 2016 Jun 13];24(4):968-75. Available from: http://www.scielo.br/pdf/tce/v24n4/pt_0104-0707tce-201500000300014.pdf

24 Althabe F, Moore JL, Gibbons L, Berrueta M, Goudar SS, Chomba E, et al. Adverse maternal and perinatal outcomes in adolescent pregnancies: the global network's maternal newborn health registry study. Reprod Health [Internet]. 2015 [cited 2016 Apr 25];12 Suppl 2:S8. Available from: http://www.ncbi.nlm. nih.gov/pmc/articles/PMC4464033/pdf/1742-475512-S2-S8.pdf 